\title{
Research on the Core Value System of Socialism and Political Cultural Construction
}

\author{
Lv Jian \\ Department of Social Science North China Institute of Aerospace Engineering, Langfang, China
}

\begin{abstract}
Core value system of socialism are the soul of the socialist system, it leads the mainstream value orientation and the selection of the value and determines the development of the political culture of socialism. The issue attempts to discuss the leading function of core socialist values to the development of the political culture of socialism from the four aspects---the common political conviction, the civic morality, the inheritance and reference and the institutional guarantee.
\end{abstract}

Key words: core value system of socialism; political culture; leading

Political culture belongs to the means of spiritual production in our human society, the existence and development of it is based on the social value system. It reflects the political demands of ruling classes and serves their political rights. Core value system of socialism is inner spirit and soul of life of the socialist system, democracy in the widest sense is the value pursue, which shows the chief idea and development direction for the future development of the political culture of socialism.

\section{Core Value System and Political Culture}

Core value system is an essential spiritual bond and value foundation of every nation and society, it regulates the patterns of political ideas and behaviors of people. In essence, core value system is the concentrated reflection of ruling class values, "the ideas of the ruling classes dominate in every times. That is, the class who is the ruling material force in a society is the ruling intellectual power at the same time. The class who controls the means of material production dominates the means of spiritual production at the same time. "( Karl Marx, Frederick Engels; 1995) Core value system is to establish a "legal and political superstructure" and a corresponding "certain form of social consciousness" based on the economic structure of society. It is the concentrated reflection of ruling class values. Core value system consists of two meanings: one is that the core value is the constructing subject of the ruling class, the other is the core value reflected by the value of production which maintained by core value system, " They regulate the production and distribution of the ideas in their times and dominate the whole society as thinkers and producers of ideas".( Karl Marx, Frederick Engels; 1995) It was a basic guarantee for the stability and the development of society, economy, politics and culture and provides legal principle and ethical support for the existence of a state system as the core and dominant in the society.

Political culture is the sum total of political cognition, political emotion, political belief and political attitude formed in the social political practice under the certain condition of social history. It is closely connected with social life, dispersing in the grand society culture, and subject to economic and political structures of the society to some extent and the social value structures based on them. It is also regulated and constrained by the core value system, reflecting the political demands of the ruling class, meanwhile, serving the political interests of the ruling class.

Members of society under the influence of the political culture will reflect a particular political value systems of consciousness and emotions in mind, constitute political attitudes and political value orientation of social members, lead with Marina about their values and behavior, which is the political system and the value support it depends on. Social value systems constitute the operational basis of political culture, a stable and effective democratic government, not just rely on the government structure and political structure: it depends on the orientation of the political process--political culture, unless political culture can support the democratic system, otherwise the chance of success of these systems would be slim. On this point, operating modes of political culture and value system are concordant.

Core value system of socialism is essential embodiment of socialist ideology, the spiritual core of the Socialist system and the fundamental spirit of building socialism with Chinese characteristics. People is the main body of this core value system. Safeguarding and achieving the interests of people are the basic criteria for evaluation of the value system. At the same time, it also regulates the thrust and direction of development of the Socialist political culture. People's democracy is the life of the Socialist. Insisting all the power belonging to the 
people and achieving the broadest people's democracy are the development direction of socialist political, which is the core of maintaining socialist political culture and political system.

\section{Basic path of Core Value System of Socialism leading the development of Socialist Political Culture}

2.1 The development of the socialist political culture must consolidate the common political beliefs based on Marxism.

In realistic politic life, as the core value system of the ideology, it is internalized as social members "political beliefs" playing a role in leading society development. Ideology is an "organized belief system, it provides a reasonable explanation of social and political phenomenon, it serves social movements and provides reasons for the execution of power. Thus, the significance of the ideological framework provided in fact enable people can say in one sense: Unfounded world for their orientation." (Thompson,J.B; 1990) Political belief constitutes the psychological foundation of political culture. The establishment of political value system based on social members' common belief provides the rationality and legitimacy for the operation of the political power and political system.

Marxism is the foundation of our Party and country, the "social cement" that unites people and enhances common intellectual foundation, and our basic political belief.

After the opium war, gradually awakening Chinese people began a hard exploration of the key to saving the nation. Countless facts prove: "the best way to develop China is to find advanced theory, which guides Chinese people's anti-imperialist and anti-feudal revolution, and to find the advanced social force to lead China's social changes." (Hu Jintao. 2011, July 2) While Chinese people have failed again and again in the struggle to find the way to save the country, Marxism from the October Revolution 1917 enlightened the Chinese in the dark. Through the study and comparative analysis of Marxism, Mao Zedong, Liu Shaoqi, Zhou Enlai, Deng Xiaoping as the representatives of a large number of advanced intellectuals gradually established a Marxist belief, and became the firm Marxists. they combined the basic principles of Marxism with Chinese characteristics of the times and the actual revolution by virtue of their myriad endeavor, opened up the revolutionary road of rural areas surrounding the city, armed seizing power with a heavy price, and made the victory of new-democratic revolution finally. "Chinese revolution could not have been achieved without our full faith of Marxism or the combination of Marxism and the concrete practice of China, China will engage in unsuccessful revolution, and is falling apart now, no independence, no unification. Belief in Marxism, is a kind of spiritual motivation of Chinese revolution victory. " (Deng Xiaoping; 1993) Owing to our adherence to Marxism-Leninism, MAO Zedong thought and theoretical innovation on the basis of the practice, China pushed the policies "Reform and Opening", triumphantly realized economic transformation from the highly centralized planned economic system to socialist market economic system, from a closed semi-closed state to all-round. Eventually China initiated the socialism with Chinese characteristics. Nowadays, Marxist value ideal, basic method and theory are still not out of date, still the ideological basis to promote socialist modernization.

\subsection{Socialist political and cultural development must be based on honor and disgrace to shape civic virtue}

All political activities are required to put the "morals" on the balance of measures, "should", "should not" concise moral reflection and political values, it is the basic means of regulating social relations, evaluation of political as well as practical subjects and its fundamental values. Establishment of political beliefs, political culture's development is inseparable from the moral strength of support. If there is no support of moral force, political culture will be like duckweed or water mist in the air, cannot withstand the impact of a variety of social thought.

Concept of honor provides basic values and norms of behavior norms for all members of society, but also for the social development of a political culture of ethical dimensions for reference. First, the socialist concept of honor as a fundamental political values scale, its legitimacy and legality can be expressed that public order and good morals are always penetrated into the various systems of social and political, economic, cultural and social life ,Its basic function is to develop socialist democratic politics, social ethics provide a good environment Second, the "eight honors and eight disgraces" formed in the political practice and ethical practices, characterized by political practice and ethical practice, it permeated with insightful discourse on political subjects highly concerned political behavior, political life and thus achieve the goal of shaping the political main political personality, and "moral people" and "political person" of integration. While, citizens consciousness can promoting people of inner moral quality accomplishment of upgrade, "in directing all our actions to promote the greatest possible good, in submitting all inferior affections to the desire of the general happiness of mankind in regarding one's self but as one of the many, whose prosperity was to be pursued no further than it was consistent with, or conductive to that of the whole, consisted the perfection of virtue" (Adam Smith; 2006) The other hand, moral beliefs and values of the individual to the State and society, the individual and the State of modern. 


\subsection{The development of the socialist political culture must regard inheritance and reference as strategy selection}

The construction of political culture of a country must also be carried out under the conditions established, it cannot be separated from the history and the reality of existence. Since the transformation of modern China's social modernization has been in the difficult process, Contemporary Chinese socialist political culture development is facing the trouble of traditional and modern, socialist and non-socialist pluralistic political culture, how to achieve from tradition in the breakout to realize the transcendency of the Western capitalism political culture which must regard heritage and reference regard inheritance and reference as strategy selection, and absorb nutrients beneficial results from their own ethnic culture and tradition of excellence in human political civilization.

The traditional culture is not calmly ignored, it is the required course of the survival and development of every nation and State. During thousands of years of history the brilliant Chinese culture have been created, this culture had supported a large and unified multi-ethnic country prosperity and development, and has become a powerful traditional deep into the cultural vein of our nation. "To its dross, take its elite "is we treats traditional of basic attitude, but " culture traditional is not a has mature, and eventually stereotypes has of ' rotten apple ', can simple to take its ' elite ', to its ' dross ', but a complex of dynamic ' live ' of life system ", " from has people and social of specific development, wanted to on culture phenomenon itself to judgment it of absolute value, determining that it is eternal of ' elite ' or ' dross ' this ideas itself is cannot established of " ( $\mathrm{Li}$ Deshun,Sun Weiping;2004) Accumulation must be content-rich, deeply rooted in traditional culture into the construction of socialist political civilization and political systems, to achieve people's democracy and achieve the development goals as a aims to socialism with Chinese characteristics, extracting its legitimacy from our traditional culture content.

It is rapid expansion of globalization that made each developing country towards political modernization have to face the impact and challenges of Western political culture. Therefore, in-depth study of Western political and cultural traditions, and with the political tradition of the cultural development of the country in contrast to political practice, analysis, integrating the active part of the political culture of the West into the nation's political development, become a prerequisite for successful development of political modernization. Therefore, we must treat the Western political culture in our own national traditions and inherent requirements of the development of socialist democratic politics with criticism and reference.

Western political culture is a set of political values and bourgeois political system which was established gradually in the struggle against the feudal autocracy, the privilege level of the opposition and constantly improved. It's starting and ending point is to maintain the maintenance of bourgeois political and the dominance of economic services. It's starting point and final goal is to preserve the bourgeoisie politically and economically dominant service. But bourgeois of anti-feudal authoritarian struggle representative has human social of development direction, "free", "democratic", "equal" and the "legal before everyone equal" and other values and principles represent the basic direction of the development of human society, are worth our learning and reference. We should abandon the limitation of the class, build value concepts and system schema which represent interests of the overwhelming majority of the Chinese people.

\subsection{The development of the socialist political culture must be based on sound system for the protection}

The political culture and political system are closely related. Any kind of political ideology is the integration of a certain amount of political cognition, emotion, values and evaluation with a certain political system, structures and policy. In a complex society, the political behavior created a "political community" and political institutions maintains its existence. "Historically, political institutions have emerged out of the interaction among and disagreement among social forces, and the gradual development of procedures and organizational devices for resolving those disagreements." (Samuel P. Huntington;1968) The development and change of the political culture are inevitable. But the revolution of the simple political value that's lack of institutional constraints could not last long, and we need to take the construction of the system to a prominent position. In a complex society, the relative strength of various social groups is constantly changing. But if the society wants to be a community, the power of each group is exercised through political institutions which temper, moderate, and redirect that power so as to render the dominance of one social force compatible with the community. "It is true that the errors we made in the past were partly attributable to the way of thinking and style of work of some leaders. But they were even more attributable to the problems in our organizational and working systems. If these systems are sound, they can place restraints on the actions of bad people; if they are unsound, they may hamper the efforts of good people or indeed, in certain cases, may push them in the wrong direction ...... I do not mean that the individuals concerned should not bear their share of responsibility, but that the problems in the leadership and organizational systems are more fundamental, widespread and long-lasting, and that they have a greater effect on the overall interests of our country. This is a question that has a close 
bearing on whether our Party and state will change political colour and should therefore command the attention of the entire Party." (Deng Xiaoping;1993).

The development and perfection of socialist political culture must be based on the binding system, an institutional force for the development of the Socialist political system for providing strong protection. Political reform must break impeded the development of socialist democratic politics thoughts and values, clear the shortcomings of institutional mechanisms through institutional innovation. The innovations of the system are in favor of Socialist democracy, the establishment of political and cultural values, such as equity and justice, progress and political stability of the structure in favor of political behavior. The construction of the socialist system, Socialist legal cultivation legal consciousness of the whole society, focused on applying thought of rule of law and the rule of law, deepening reform, promoting development, resolve conflicts and maintain stability and strive to create a scientific legislation and strict law enforcement, justice, all law-abiding good environment governed by law.

\section{References}

[1]. Karl Marx, Frederick Engels (1995). MARX ENGELS SELECTED WORKS (Central Compilation \& Translation Bureau, Trans.). Beijing:People's Press (Original work published 1924),98,99.

[2]. Thompson,J.B.(1990).Ideology and Modern Culture. Cambridge Polity Press, 89.

[3]. Hu Jintao.(2011, July 2).To celebrate the 90 anniversary of the founding of the Communist Party in Chinese speech. People's Daily.

[4]. Deng Xiaoping.(1993). Selected Works Of Deng Xiaoping(Vols. 3). Beijing: People's Press, 63.

[5]. Adam Smith.(2006) .The theory of moral sentiments(sixth edition). Cambridge :Cambridge University Press,276.

[6]. Li Deshun,Sun Weiping..(2004).The spirit and the dross: tradition is not a "rotten apple",JOURNAL OF HUNAN UNIVERSITY \& TECHNOLOGY,4,57-60.

[7]. Samuel P. Huntington.(1968).Political Order In Changing Societies. Yale University Press,11.

[8]. $\quad$ Deng Xiaoping.(1993). Selected Works Of Deng Xiaoping(Vols. 2). Beijing:People's Press,333. 